\title{
LE CONTRÔLE INDIVIDUEL DES JEUNES TRUIES A L'ÉLEVAGE
}

\author{
R. KERISIT, J. NAVEAU et J. GODET \\ Institut Technique du Porc, \\ 130, Canal Saint-Martin, 35 - Rennes
}

\section{RÉSUMÉ}

Démarré en I968, le contrôle individuel des truies à l'élevage a connu une extension très rapide : 3 ooo animaux contrôlés en I968 et 8700 en I969.

Jusqu'à présent, cette méthode de sélection de jeunes truies a surtout été utilisée dans un cadre de développement et de démonstration auprès des éleveurs. Cependant un certain nombre d'élevages ont pratiqué des contrôles régulièrement.

Ainsi dans 43 élevages, pour lesquels les mouvements d'animaux dans le cheptel ont pu être obtenus, nous avons essayé d'effectuer une analyse de l'utilisation de la méthode en établissant un classement sur les deux points suivants :

- le taux de sélection pratiqué.

- 1'utilisation des possibilités de sélection.

Il en ressort que 9 élevages ont pratiqué un taux de sélection acceptable (3 I p. roo) sans toutefois avoir pleinement utilisé les possibilités de sélection. 9 autres ont réalisé un taux moyen, et les plus nombreux (25) ont pratiqué un taux de sélection dérisoire (7\% p. 100), accompagné probablement d'une politique de vente systématique des animaux contrôlés.

Quelques élevages de groupements de producteurs semblent avoir tiré un certain profit des contrôles. Mais beaucoup d'efforts doivent être accomplis pour que cette méthode de sélection, basée sur la mesure de caractères économiquement importants, atteigne une certaine efficacité.

\section{SUMMARY}

\section{INDIVIDUAL, PERFORMANCE TEST OF YOUNG SOWS AT THE FARM}

The extension of the individual performance tests of the sows at the farm, started in 1968 has been very rapid : 3 ooo animals tested in 1968 and 8700 in 1969 .

Up to now, this method of testing young sows at the farm was a part of the programme of development and demonstration applied to the farmers. However, certain number of farms carried out this kind of tests regularly.

Thus, in 43 farms, in which arrivals and departures of animals in the herd were recorded, we tried to analyse the utilization of the method by establishing a classification according to the two following points :

- the selection rate applied.

- the utilization of the possibilities of selection. 
The result was that 9 farms used an acceptable selection rate (3 $\mathrm{I}$ p. roo), without taking advantage, however, of all the possibilities of selection. 9 other farms applied an intermediate rate, but most of the farms (25) used a very bad selection rate (7० p. 10o), probably accompanied by a systematic sale of the tested animals.

It seems that some groups of animal breeders have taken a certain advantage of these tests. However, much work must be done to attain a certain efficiency from this method of selection based upon the measurement of economically important characters. 